\title{
Toxicity assessment on haemotology, biochemical and histopathological alterations of silver nanoparticles-exposed freshwater fish Labeo rohita
}

\author{
K. S. Rajkumar $\cdot$ N. Kanipandian $\cdot$ R. Thirumurugan
}

Received: 10 October 2014 / Accepted: 9 February 2015/Published online: 19 February 2015

(C) The Author(s) 2015. This article is published with open access at Springerlink.com

\begin{abstract}
The increasing use of nano based-products induces the potential hazards from their manufacture, transportation, waste disposal and management processes. In this report, we emphasized the acute toxicity of silver nanoparticles (AgNPs) using freshwater fish Labeo rohita as an aquatic animal model. The AgNPs were synthesized using chemical reduction method and the formation of AgNPs was monitored by UV-Visible spectroscopy analysis. The functional groups, crystaline nature and morphological characterizations were carried out by fourier transform infrared spectroscopy (FTIR), X-ray diffraction (XRD) and high resolution transmission electron microscopy (HRTEM) analysis. UV-Vis range was observed at $420 \mathrm{~nm}$ and XRD pattern showed that the particles are crystalline nature. HRTEM analysis revealed that the morphology of particles was spherical and size ranges between 50 and $100 \mathrm{~nm}$. This investigation was extended to determine the potential acute toxicity, L. rohita was treated orally with the lethal concentration $\left(\mathrm{LC}_{50}\right)$ of AgNPs. The antioxidative responses were studied in the three major tissues such as gill, liver and muscle of $L$. rohita. The results of this investigation showed that increasing the concentration of AgNPs led to bioaccumulation of AgNPs in the major tissues. The haematological parameters showed significant alterations in the treated fish. The histological changes caused by chemically synthesized AgNPs demonstrated the damages in the tissues, primary lamella and blood vessels of $L$. rohita. The histological study also displayed the formation of
\end{abstract}

K. S. Rajkumar · N. Kanipandian · R. Thirumurugan ( $\square)$ Laboratory of Aquabiotics/Nanoscience, Department of Animal Science, School of Life Sciences, Bharathidasan University, Tiruchirappalli 620 024, Tamil Nadu, India e-mail: ramthiru72@gmail.com vacuolation in liver and muscle when compared with untreated tissues (control) of L. rohita.

Keywords Labeo rohita - Silver nanoparticles - Acute toxicity · Oxidative stress · Histopathology

\section{Introduction}

In recent years there is an increasing demand for the nanoparticles in the field of metal industries, and biomedical science etc. Nowadays the nanoparticles are even used in the household appliances. Nanotoxicology is a study of impact of manufactured nanomaterials on living organisms and environment. It also deals with the quantitative evaluation of severity and frequency of nanotoxic effects in relation to the exposure of the organisms. Metal nanoparticles have been used in various fields such as consumer products, industrial applications and health care technology are likely to enter the environment (Masciangioli and Zhang 2003; Nohynek et al. 2007; Benn and Westerhoff 2008) stated that the AgNPs are commonly used in the textiles and these nanoparticles might be released into the environment. The toxicological evidence of AgNPs is still lacking and the safety measurements for these nanoparticles have to be framed. The engineered nanomaterials comprise of numerous different physical forms and some of these materials including carbon nanotubes, carbon spheres called fullerenes (Zhu et al. 2006) and nanoparticles made from metals (Griffitt et al. 2007), metal oxides (Federici et al. 2007) or composites made of several metals (King-Heiden et al. 2009) have adverse effects on fish (Smith et al. 2007). To study the aquatic toxicity, fish species has been widely used as an indicator of pollutant and they strongly respond to stress conditions. 
An earlier report of Ramesh et al. (2013) emphasized the toxicological impact of $\mathrm{SiO}_{2}$ nanoparticles on antioxidant enzymes and DNA strand break using zebra fish (Danio rerio). Earlier literatures have also been discussed about the pathological alterations at morphological level in various severities in different fish organs (Lemaire-Gony and Lemaire 1992; Battaglini et al. 1993).

ROS-mediated oxidative damage to macromolecules namely lipids, proteins and DNA have been implicated in the pathogenicity of major diseases. The oxidative stress implicated in the pathology of a number of disorders, such as atherosclerosis, ischemia-reperfusion injury, cancer, malaria, diabetes, inflammatory joint disease, asthma, cardiovascular diseases, cataracts, immune system decline, play a role in neurodegenerative diseases and aging processes (Young and Woodside 2001). Furthermore, nanoparticles are also shown to cause toxicity by increasing concentration of intracellular ROS and decrease in antioxidant level (Singh et al. 2009; Hussain et al. 2009). The increase in ROS level is also an important indication of predominant mechanism of acute toxicity (Kaewamatawong et al. 2006). In this study, synthesized AgNPs were assessed to explore the acute toxicity effects using Labeo rohita as an in vivo model. These findings would provide essential information regarding the potential toxicities and biodistribution of AgNPs in the fish model.

\section{Materials and methods}

Synthesis of AgNPs

The AgNPs were synthesized using chemical reduction method of Rashid et al. (2013), with minor modifications. Silver nitrate $(0.1 \mathrm{M}), 0.8 \mathrm{~g}$ of trisodium citrate and $0.1 \mathrm{~g}$ of sodium borohydride were freshly prepared. These three solutions were mixed with equal volume $(2 \mathrm{~mL})$ and finally made up to $200 \mathrm{~mL}$ with distilled water $(\mathrm{pH} \mathrm{8.0)}$. The reaction mixture was stirred continuously at room temperature for $3 \mathrm{~h}$ and the colour change of the reaction was noticed. The solution was centrifuged at $6000 \mathrm{rpm}$ for 20 min followed by distilled water to purify the reaction mixture. Finally, the pellet was made into powdered form and stored for further studies.

\section{Characterization of AgNPs}

\section{UV-Visible spectroscopy}

The characterization of synthesized AgNPs was carried out using UV-Visible spectroscopy. The reduction of AgNPs was monitored by measuring the absorbance of reactions mixture at the range of 200-700 nm using synergy HT multi-mode microplate reader (Biotek Instruments, Inc, Winooksi, VT, USA).

\section{$X$-ray diffraction $(X R D)$}

The AgNPs were subjected to XRD analysis using PAN analytical-XPERT-PRO diffractometer system, Eindhoven, Netherlands and the target was $\mathrm{Cu} K \alpha$ radiation with a wavelength of $1.54 \AA$, the generator was operated at $40 \mathrm{kV}$ and with a $30 \mathrm{~mA}$ current. The average grain size of AgNPs was determined using Scherrer's formula. $D=0.94 \lambda / \beta \cos \theta$, where, $D$ is the average crystal size, $k$ is the Scherer coefficient $(0.94), \lambda$ is the $\mathrm{x}$-ray wavelength, $\theta$ is Bragg's angle and $\beta$ is the full width at half maximum in radians.

\section{FTIR and HRTEM analysis}

FTIR spectroscopy was used to identify the possible functional groups involved in the reduction of silver ions. The FTIR spectra of synthesized AgNPs were analyzed in the range of $400-4000 \mathrm{~cm}^{-1}$ and the measurement was carried out by JASCO (FTIR-6200) spectrum. The size and morphological nature of the AgNPs were determined using transmission electron microscope (JEOL-JEM-200 CX).

\section{Experimental animal and acute toxicity assessment of AgNPs}

The experimental animal L. rohita was collected from local fish pond and maintained in the aquarium separately. The experimental aquaria were aerated and test media were replaced every day. The laboratory temperature was $28 \pm 2{ }^{\circ} \mathrm{C}$ and normal illumination (approx $12 \mathrm{~h}$ light and $12 \mathrm{~h}$ dark) was maintained throughout the experimental period. Acute toxicity effect of AgNPs was investigated on L. rohita. All experiments were carried out for a period of 7 days and lethal concentration $\left(\mathrm{LC}_{50}\right)$ was determined with five different concentrations (25, 50, 100, 500, $1000 \mathrm{mg} \mathrm{kg}^{-1}$ ) of AgNPs. Among these concentrations, mortality rate was found at two concentrations (500 and $1000 \mathrm{mg} \mathrm{kg}^{-1}$ ). Hence, $100 \mathrm{mg} \mathrm{kg}^{-1}$ concentration was used as a maximum value for further experimental studies. For sub-acute toxicity tests, the $\mathrm{LC}_{50}$ concentration of AgNPs in water was maintained modestly below value such as 5, 10, 25, 50 and $100 \mathrm{mg} \mathrm{kg}^{-1}$ and AgNPs were orally introduced to the fish. After 7 days of sub-lethal exposure, the blood samples were collected and the experimental fishes were sacrificed and muscle, gill and liver were dissected out to assess the toxic impact of AgNPs in fish by analyzing haematological, antioxidant enzymes and histological parameters. 


\section{Analysis of haematological parameters}

The Haemoglobin content, total protein, total erythrocytes and leukocytes count of the blood was estimated. The blood samples were collected and immediately subjected to haematological analysis. The RBC and WBC were diluted with appropriated diluting fluids and the total content was calculated using improved Neubauer haemocytometer (Blaxhall 1972). The Sahli's haemoglobinometer was used to estimate haemoglobin (HB) content of the AgNPstreated fish as well as in control.

Effect on tissue-damaging enzymes

\section{Estimation of acid phosphatase (ACP) and alkaline phosphatase (ALP)}

Acid phosphatase (ACP) and alkaline phosphatase (ALP) activities were estimated according to Michell et al. (1970) and Estiarte et al. (2008). The reaction medium for ACP contained $0.7 \mathrm{ml}$ sodium acetate buffer (pH 5.0), $0.25 \mathrm{ml}$ p-nitrophenyl phosphate (pNPP, $5 \mathrm{mM}$ ) as substrate and $0.05 \mathrm{ml}$ of enzyme totaling to $1 \mathrm{ml}$ was incubated for $30 \mathrm{~min}$ at $37^{\circ} \mathrm{C}$. The reaction was stopped by adding $4 \mathrm{ml}$ $\mathrm{NaOH}(0.1 \mathrm{~N})$ and incubated for another $30 \mathrm{~min}$ at $37^{\circ} \mathrm{C}$. The reaction medium for ALP contained $0.5 \mathrm{ml}$ glycine buffer ( $\mathrm{pH} 7.8), 0.2 \mathrm{ml}$ magnesium chloride $(10 \mathrm{mM})$, $0.25 \mathrm{ml}$ p-nitrophenyl phosphate (pNPP, $5 \mathrm{mM}$ ) as substrate and $0.05 \mathrm{ml}$ of enzyme totaling to $1 \mathrm{ml}$ was incubated for $30 \mathrm{~min}$ at $37^{\circ} \mathrm{C}$. The reaction was stopped by adding $4 \mathrm{ml}$ $\mathrm{NaOH}(0.02 \mathrm{~N})$ and incubated for another $30 \mathrm{~min}$ at $37^{\circ} \mathrm{C}$. The estimation involves measurement of yellow colour of p-nitrophenol in a synergy HT Multi-Mode Microplate Reader, (Bio-Tek Instruments, Inc., Winooski, VT, USA).

\section{Catalase (CAT)}

Catalase activity was assayed by the method of Caliborne (1985). The decomposition of $\mathrm{H}_{2} \mathrm{O}_{2}$ was measured by the decrease in the absorbance at $240 \mathrm{~nm}$. The reaction mixture contained $50 \mathrm{mM}$ phosphate buffer $(\mathrm{pH}$ 7.2) and $50 \mathrm{mM} \mathrm{H} \mathrm{O}_{2}$, the reaction rate was measured at $240 \mathrm{~nm}$. The extinction coefficient of $\mathrm{H}_{2} \mathrm{O}_{2}$ was $40 \mathrm{M}^{-1} \mathrm{~cm}^{-1}$. One unit of catalase was defined as $1 \mu \mathrm{mol}$ of $\mathrm{H}_{2} \mathrm{O}_{2}$ degraded $\mathrm{min}^{-1} \mathrm{mg}^{-1}$ protein.

\section{Glutathione-s-transferase (GST)}

The GST activity was determined using the method of Habig et al. (1974). The reaction mixture $(3 \mathrm{ml})$ contained $1.0 \mathrm{ml}$ of $0.3 \mathrm{mM}$ phosphate buffer (pH 6.5), $0.1 \mathrm{ml}$ of $30 \mathrm{mM}$ 1-chloro-2, 4-dinitrobenzene (CDNB) and $1.7 \mathrm{ml}$ of double distilled water. After pre-incubating the reaction mixture at
$37{ }^{\circ} \mathrm{C}$ for $5 \mathrm{~min}$, the reaction was started by the addition of $0.1 \mathrm{ml}$ of tissue homogenate and $0.1 \mathrm{ml}$ of glutathione as substrate. The absorbance was followed for $3 \mathrm{~min}$ at $340 \mathrm{~nm}$ and reaction mixture without the enzyme was used as blank. The activity of GST was expressed as $\mu$ moles of GSHCDNB conjugate formed $\min ^{-1} \mathrm{mg}^{-1}$ protein.

Superoxide dismutase (SOD)

SOD activity was analyzed using the method of Marklund and Marklund (1974). In this test, the degree of inhibition of pyrogallol autoxidation by supernatant of the lenticular homogenate was measured. The change in absorbance was read at $470 \mathrm{~nm}$ against blank every minute for $3 \mathrm{~min}$ on a $\mathrm{Mi}$ croplate Reader (Synergy HT Multi-Mode Microplate Reader, Bio-Tek Instruments, Inc., Winooski, VT, USA). The enzyme activity was expressed as units per milligram protein.

\section{Histopathological analysis}

Samples of muscle, gill and liver tissues for histological assessment were fixed in $4 \%$ paraformaldehyde in $0.1 \mathrm{M}$

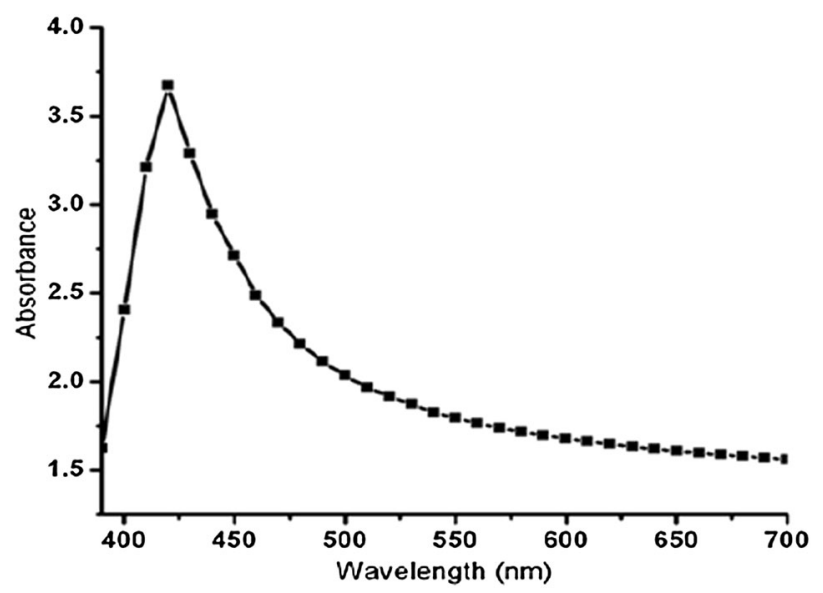

Fig. 1 Shows the UV-Visible spectroscopic analysis of AgNPs

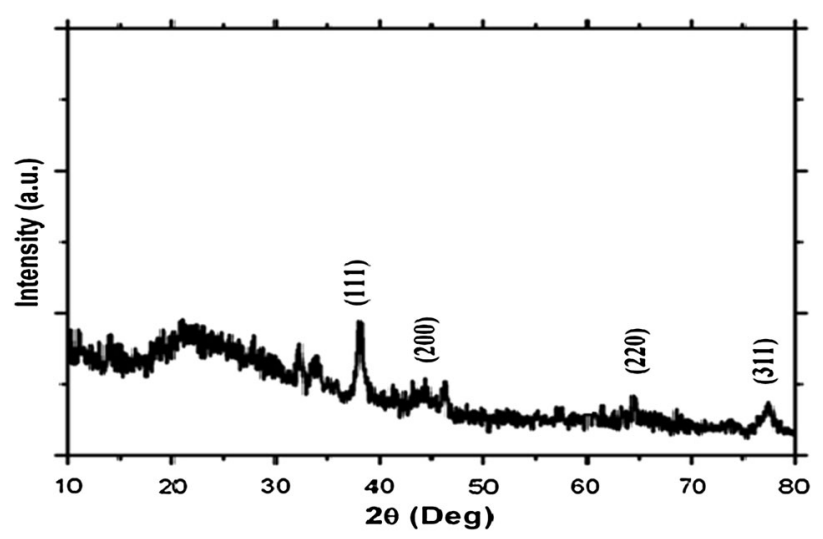

Fig. 2 XRD pattern displayed the crystalline nature of AgNPs 
phosphate-buffered solution $(\mathrm{pH} 7.4)$ at $4^{\circ} \mathrm{C}$, dehydrated in ethanol and embedded in paraplast (Takashima and Hibiya 1995). The histological sections ( $5 \mathrm{~mm}$ thick) were cut with a rotary automatic microtome and sections were mounted on glass slides. Finally, the slides were stained with haematoxylin/eosin to visualize typical morphological features.

Fig. 3 FTIR analysis of chemically synthesized AgNPs

Fig. 4 HRTEM images of AgNPs clearly showed a monodispersed and $\mathbf{b}$ and $\mathbf{c}$ spherical shape of the AgNPs. d Showed the SAED pattern of particles in crystalline nature

\section{Results and discussion}

In the present study, AgNPs were synthesized by chemical reduction method and primarily confirmed by the colour change of the reaction mixture from colourless to yellowish brown colour. The appearance of a yellowish brown colour is an indication of the formation of AgNPs (Vignesh et al.

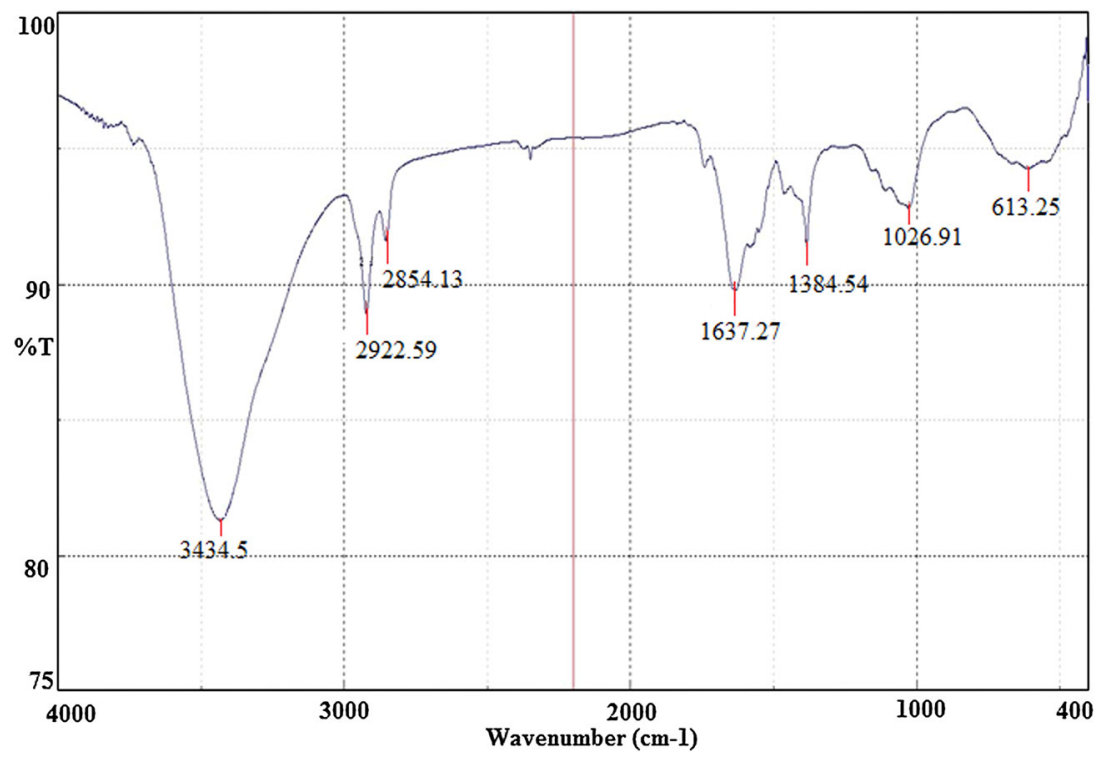

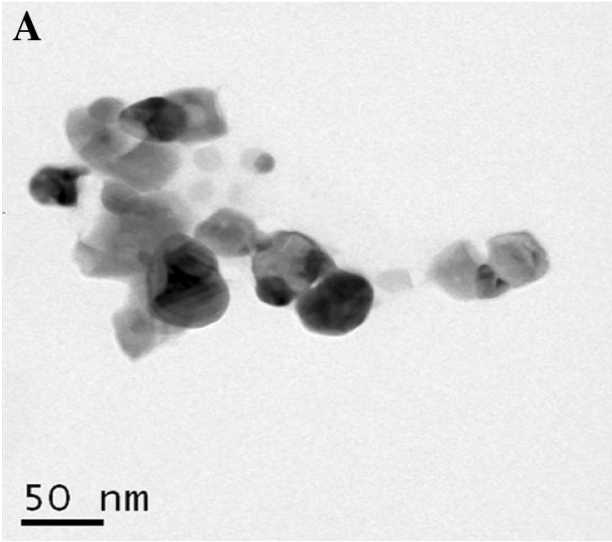

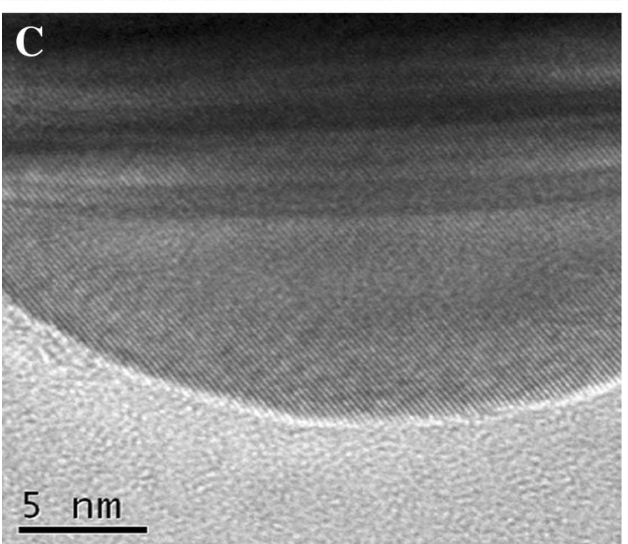

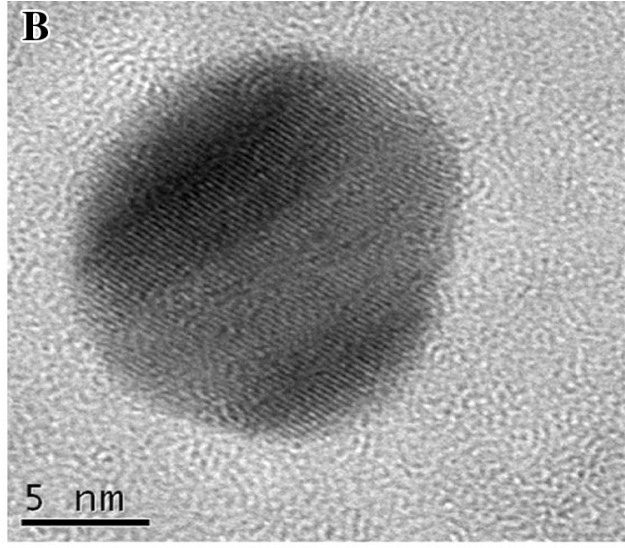

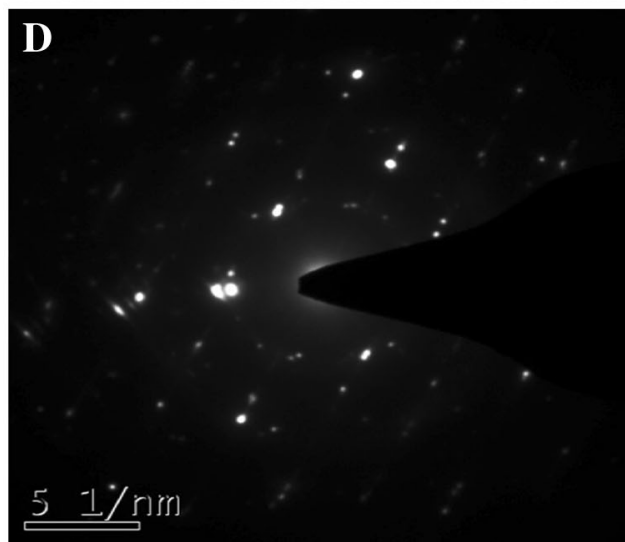


2013). Here, we have used trisodium citrate and sodium borohydrate as reducing agents. UV-Visible absorption spectra of AgNPs formed in the reaction media was recorded at $420 \mathrm{~nm}$ (Fig. 1). Under the UV region, AgNPs give a characteristic absorbance band due to the excitation mode of their surface plasmon which is dependent on the nanoparticle size (Vivek et al. 2012; Kanipandian and Thirumurugan 2014). The earlier reports have concluded that AgNPs production from fungi extract Rhizopus stolonifer (Banu et al. 2011) and plant extract Rhizophora apiculata (Antony et al. 2011) showed maximum absorbance at 422 and $423 \mathrm{~nm}$, respectively.

\section{X-ray diffraction analysis}

The phase purity and crystalline nature of AgNPs were determined by powder XRD study (Fig. 2). The XRD spectrum showed four distinct diffraction peaks at $\sim 38^{\circ}$, $46^{\circ}, 64.4^{\circ}$, and $77^{\circ}$ and these peaks correspond to $\left(\begin{array}{lll}1 & 1 & 1\end{array}\right)$, (2 00 0), (2 22 2) and (3 111 ) planes of face-centered cubic (fcc) silver phase (Kanipandian et al. 2014). The obtained XRD results were closely associated with the standard card (JCPDS file no. 65-2871). The average size of AgNPs formed in the present investigation was estimated by determining the full width at half maximum (FWHM) of the Bragg's angle and the estimated mean size was $96 \mathrm{~nm}$.

\section{FTIR analysis}

FTIR image of chemically synthesized AgNPs is given in Fig. 3 and the FTIR spectrum was analyzed between the ranges of $\sim 400-4000 \mathrm{~cm}^{-1}$ and showed seven broad intense bands at $\sim 3434.6,2922.59,2854.13,1637.27$, 1384.64, 1026.64 and $613.25 \mathrm{~cm}^{-1}$, respectively. The
Fig. 5 Illustrates the toxic impact of chemically synthesized AgNPs on Haematological parameters of Labeo rohita
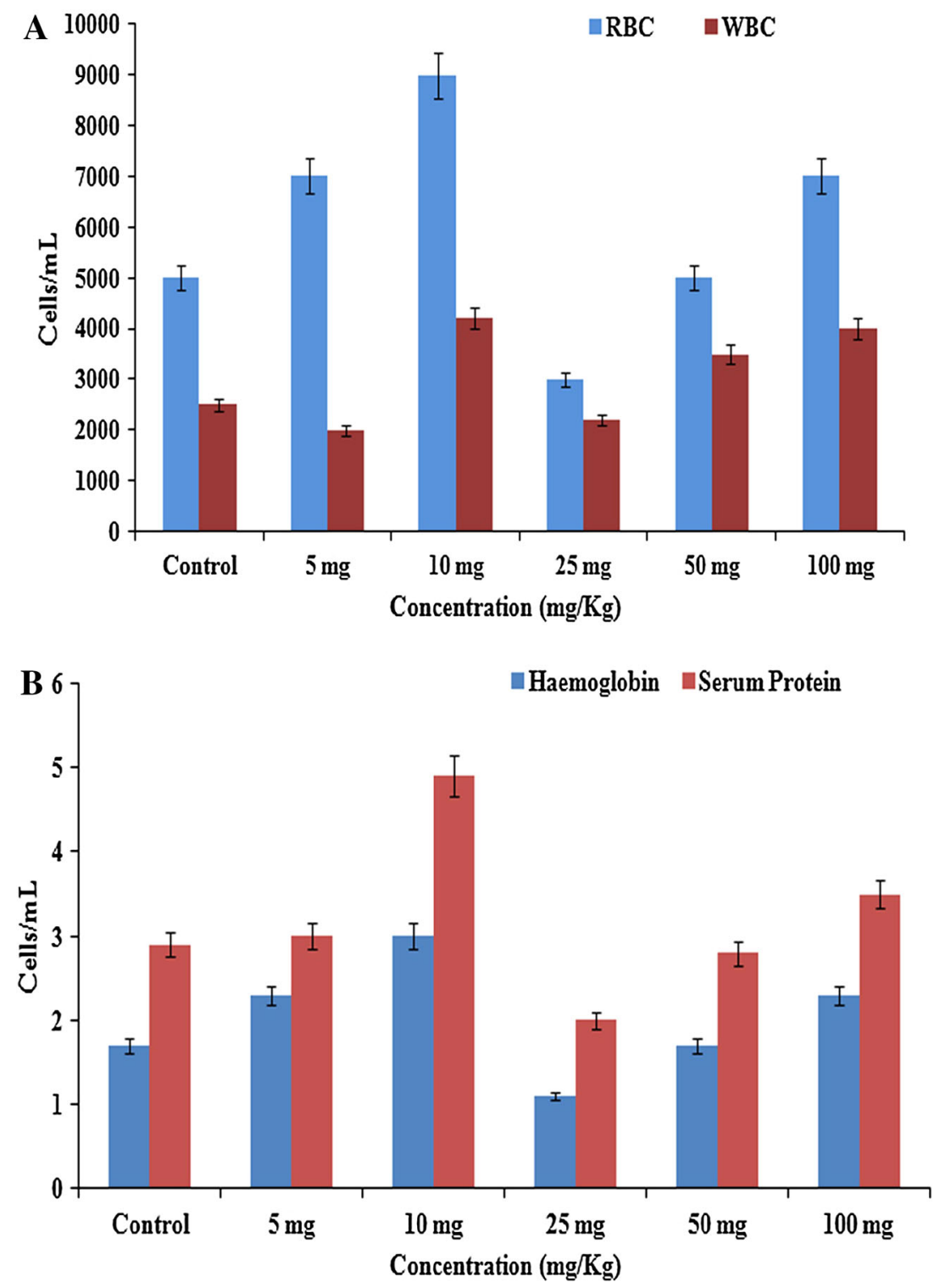
bands at $\sim 3434.6$ and $2922.59 \mathrm{~cm}^{-1}$ attributed to heterocyclic amine, $\mathrm{NH}$ stretch and methylene $\mathrm{C}-\mathrm{H}$ asymmetri$\mathrm{cal} /$ symmetrical stretch. The band at $\sim 2854.13 \mathrm{~cm}^{-1}$ indicated the presence of asymmetric $\mathrm{C}-\mathrm{H}$ stretch of the methyl and methylene groups. The FTIR peaks at $\sim 1637.27$ and $1384.64 \mathrm{~cm}^{-1}$ contributed to amide and stretching vibration of $\mathrm{NO}^{3-}$ ion present in the nanocomposite (Paulraj et al. 2011). The intense peaks at $\sim 1026.64$ and $613.25 \mathrm{~cm}^{-1}$ denote the primary amine, $\mathrm{CN}$ stretch and alkyne $\mathrm{C}-\mathrm{H}$ bends.

\section{Electron microscopy studies}

The size and morphological structure of synthesized AgNPs were studied by HRTEM (Fig. 4). These analyses revealed the presence of nano-sized materials in the suspension, which showed that the structure of nanoparticles were spherical in nature. The HRTEM clearly demonstrated that the particles were well dispersed and not severely agglomerated. The size distribution of the AgNPs displayed the average particle size ranging from 50 to $100 \mathrm{~nm}$ and SAED pattern confirmed the crystalline nature of the particles and agreed to XRD pattern (Fig. 4d).

\section{Acute toxicity of AgNPs}

To determine $\mathrm{LC}_{50}$ value of AgNPs, the experimental fish (L. rohita) was treated orally with different dosage levels $\left(25,50,100,500\right.$ and $\left.1000 \mathrm{mg} \mathrm{kg}^{-1}\right)$ of AgNPs. After the treatment period (7 days), the mortality in each group was observed and recorded carefully. The chemically synthesized AgNPs showed a dose dependent activity and mortality was increased with increasing the concentrations of AgNPs. The $100 \%$ of mortality rate was observed at 500 and $1000 \mathrm{mg} \mathrm{kg}^{-1}$ concentration and no mortality was noticed in the lowest concentrations such as 25 and $50 \mathrm{mg} \mathrm{kg}^{-1}$ of AgNPs. The $50 \%$ of mortality was observed at $100 \mathrm{mg} \mathrm{kg}^{-1}$ concentration and no mortality was recorded in control fishes during the tests. Hence, the further studies such as haematological impact, enzymes level
Fig. 6 Analysis of toxicity effect of AgNPs on major tissues of Labeo rohita using tissue-damaging enzymes a ACP and b ALP
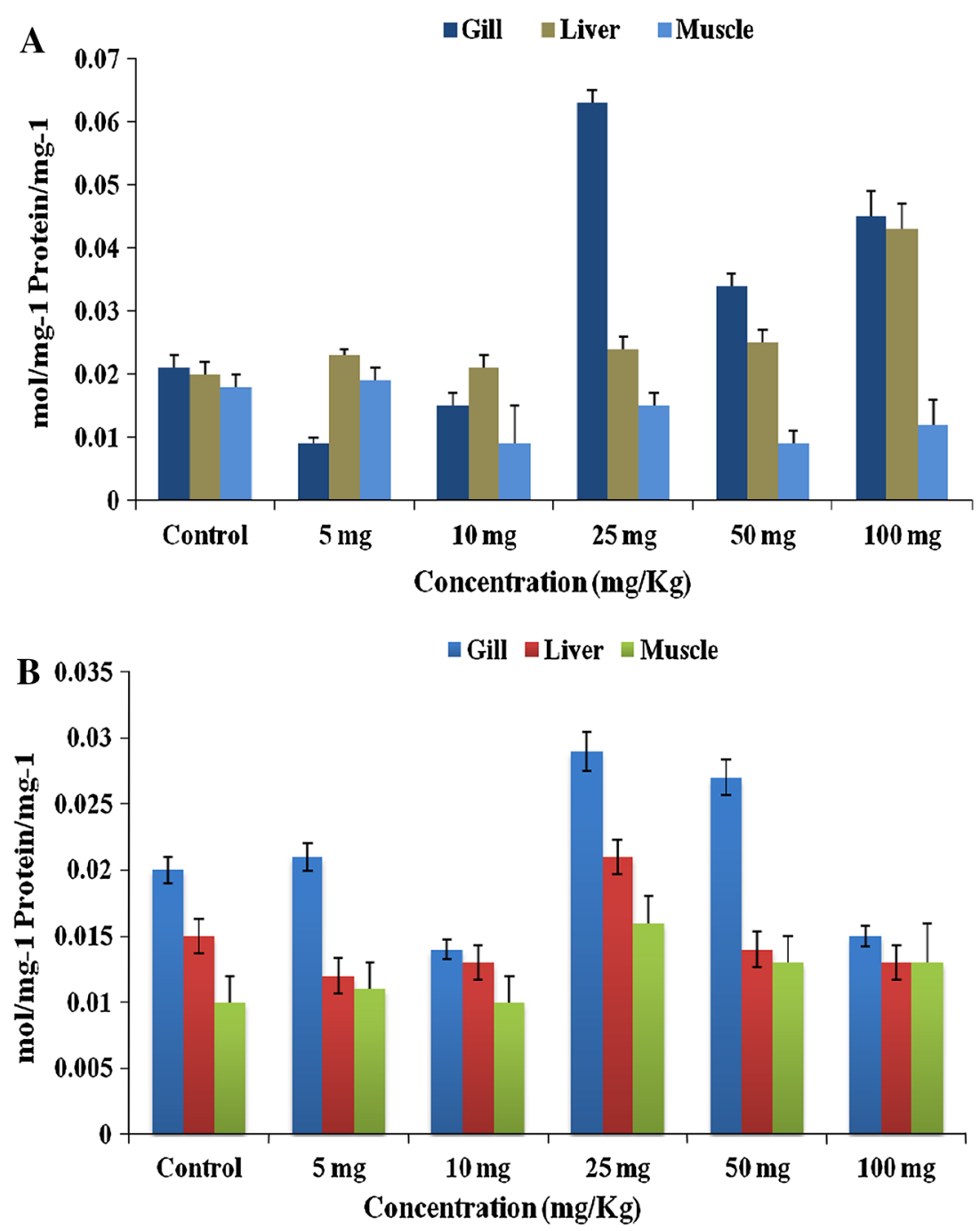
and histological study were analyzed below the concentration of $\mathrm{LC}_{50}$ value. The similar $\mathrm{LC}_{50}$ value $100 \mathrm{mg} \mathrm{L}^{-1}$ was estimated in $\mathrm{TiO}_{2}$-treated Danio rerio (Diniz et al. 2013; Xiong et al. 2011).

Haematological parameters

The alterations in RBC, WBC, haemoglobin and total serum protein level were analyzed. From the haematological investigation, we concluded that the levels of all the haematological parameters mentioned above were reduced at $25 \mathrm{mg} \mathrm{kg}^{-1}$ concentration when compared with other concentrations and control fish samples (Fig. 5). The changes in the haematological parameters might be a result of stressful conditions which affect the metabolism and normal functioning of the fish physiology (Blaxhall 1972). There were no significant alterations observed at other concentrations and the level was increased with increasing the concentration of AgNPs.

Effect on enzymes activities

The tissue-damaging enzymes such as acid phosphatase (ACP) and alkaline phosphatase (ALP) levels were
Fig. 7 Depicts the toxicity effect of AgNPs on antioxidant enzymes a GST, b CAT, c SOD
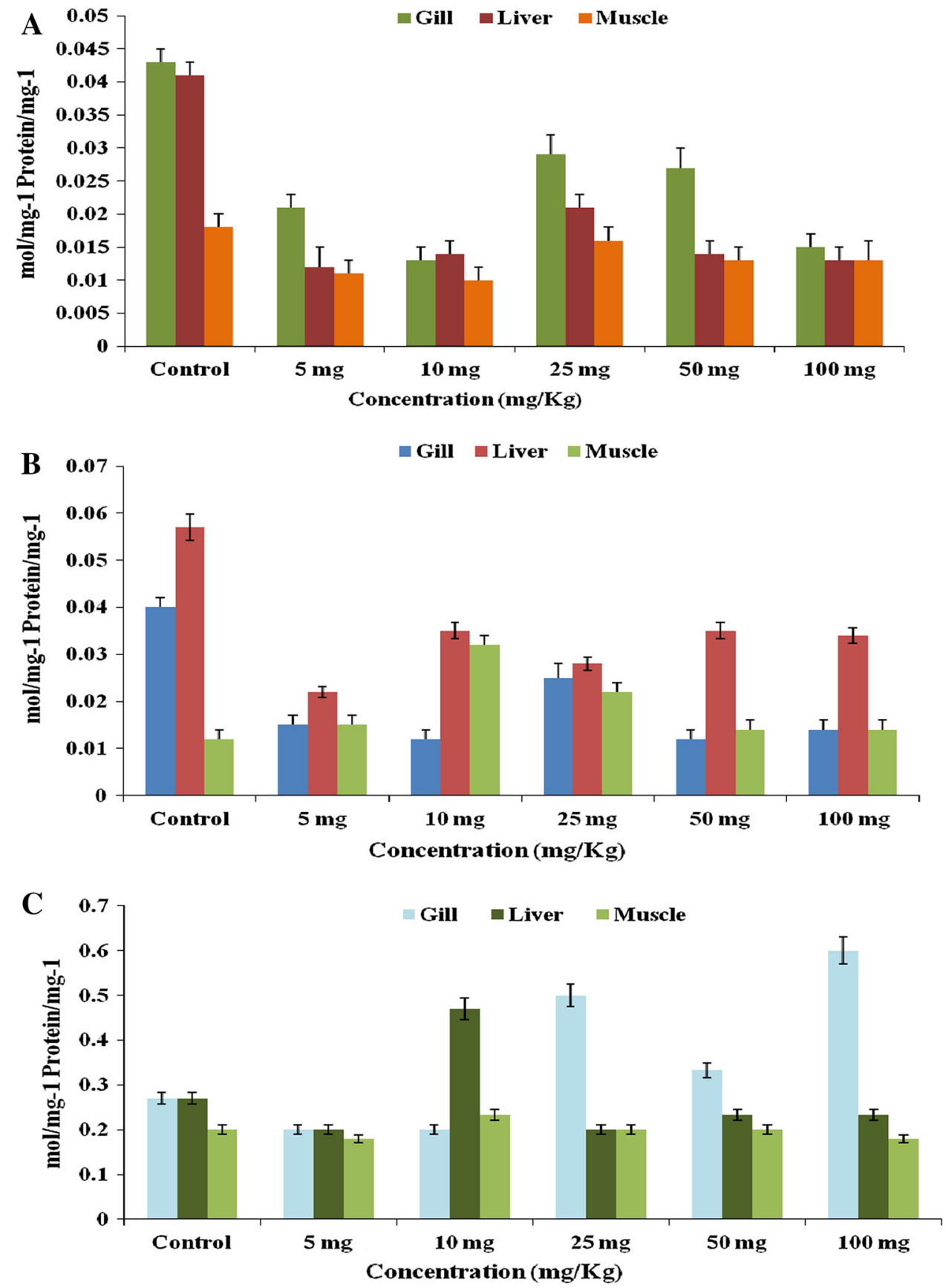

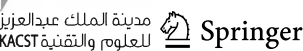


significantly higher in the AgNPs-treated fish tissues of gill, liver and muscle when compared with control tissues (Fig. 6). These results revealed that the tissue-damaging effect was caused by AgNPs. The elevation of these enzymes in the tissues was dose dependent and the higher concentrations of the AgNPs exhibited more enzyme activity.

Oxidative stress is the result of an inequity in the pro-oxidant/antioxidant homeostasis. The activities of antioxidant enzymes in the treated fish tissues such as liver, gill and muscle were assessed. The oral administration of AgNPs caused a significant reduction in the activities of glutathione-s-transferase (GST), catalase and superoxide dismutase (SOD). The treated liver tissue showed the highest changes in antioxidant enzyme activity among the tissues (Fig. 7). The AgNPs can cause the oxidative stress, leading to the depletion of antioxidant enzymes activities. A significant decrease in
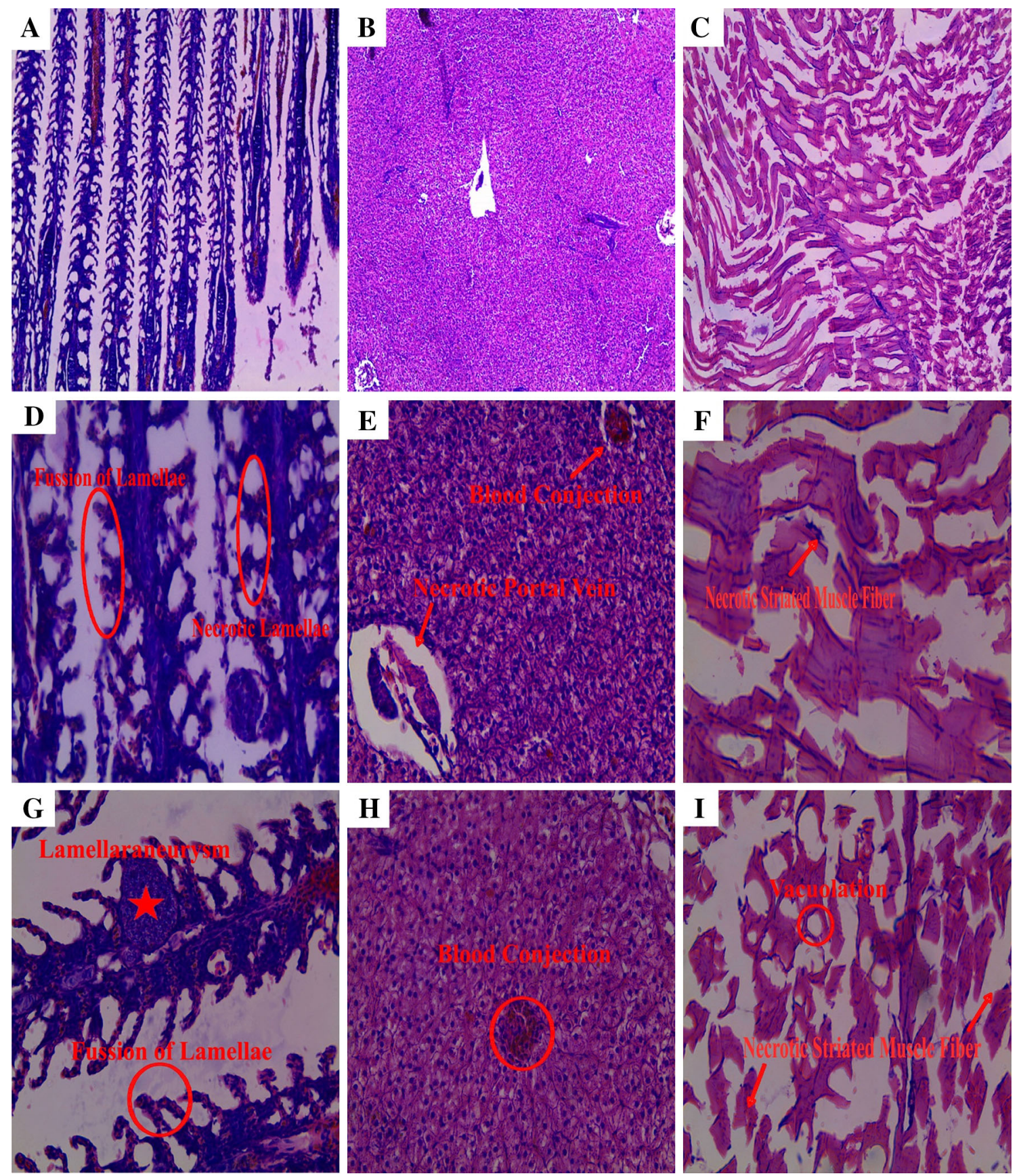

Fig. 8 The images demonstrate the histopathological study of AgNPs-treated gill, liver and muscle tissues of Labeo rohita. The control (a, b and c), $5 \mathrm{mg} \mathrm{kg}^{-1}$ concentration $(\mathbf{d}, \mathbf{e}$ and $\mathbf{f})$ and $10 \mathrm{mg} \mathrm{kg}^{-1}$ concentration $(\mathbf{g}, \mathbf{h}$ and $\mathbf{i})$ are displayed 
GST, catalase and SOD activity was observed in all treated tissues when compared with control tissues. The mechanism behind this is the metallic nature of nanoparticles and the presence of transition metals encourages the production of reactive oxygen species (ROS) leading to oxidative stress (Mac Nee and Donaldson 2003; Jia et al. 2009).
Histopathological studies

The histopathological changes were observed in gill, liver and muscle tissues of $L$. rohita due to toxicity caused by AgNPs (Figs. 8, 9).

In control, no recognizable changes were observed in gill tissue during the experimental period. It showed
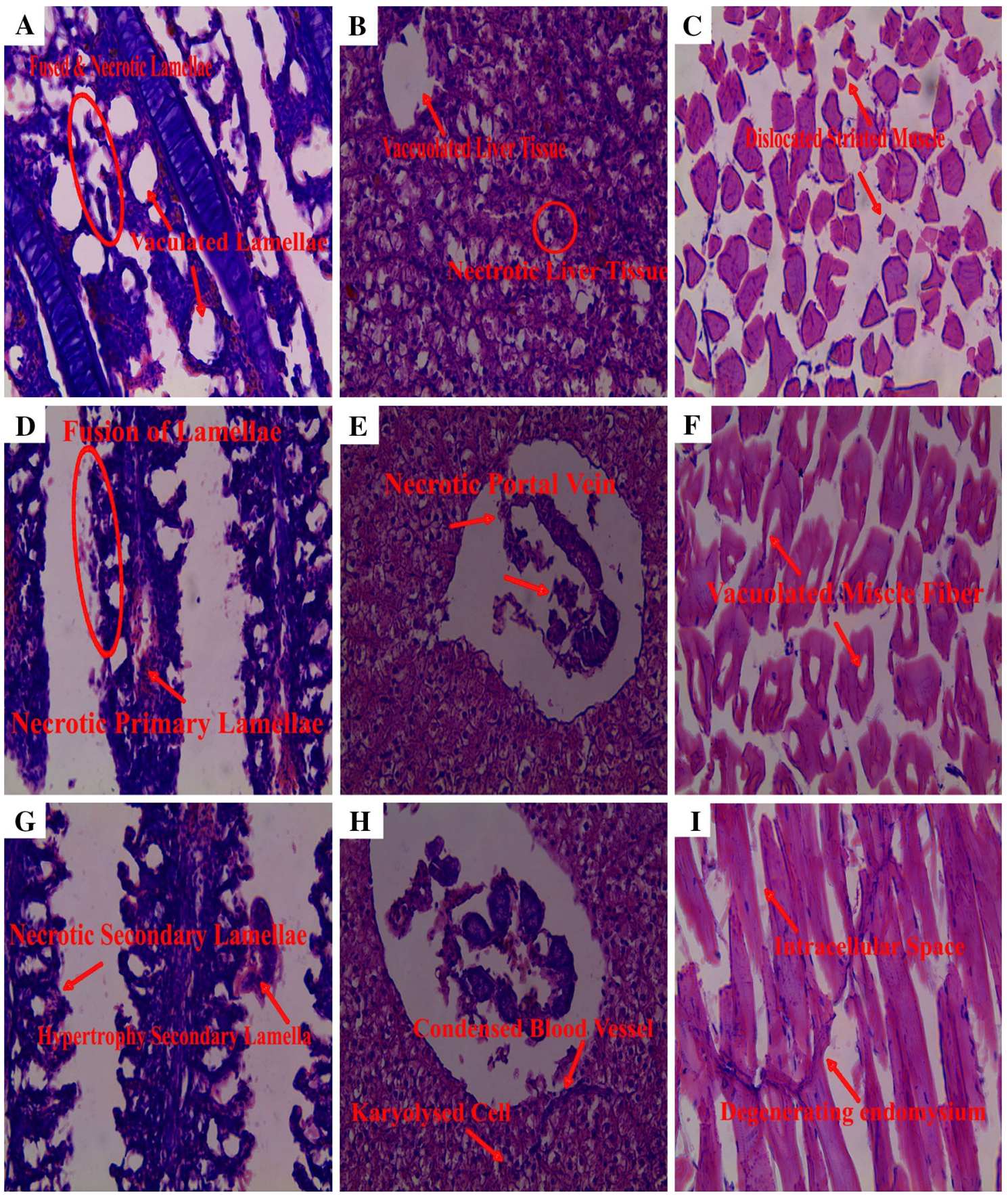

Fig. 9 The histopathological investigation of AgNPs-treated gill, liver and muscle tissues of Labeo rohita at $25 \mathrm{mg} \mathrm{kg}^{-1}$ concentration (a, b and c), $50 \mathrm{mg} \mathrm{kg}^{-1}$ concentration (d, $\mathbf{e}$ and $\left.\mathbf{f}\right)$ and $100 \mathrm{mg} \mathrm{kg}^{-1}$ concentration $(\mathbf{g}, \mathbf{h}$ and $\mathbf{i})$ are showed 
primary and secondary lamellae with pillar cells and also it consists of central venous sinus, chloride cells. The AgNPs-treated fish groups exhibited proliferation of bronchial chloride cells that leads to lamellae fusion and formation of aneurism. The aneurism was localized, bloodfilled balloon-like bulge of a blood vessel. It increases a significant risk of rupture, resulting in severe haemorrhage, other complications or death. These similar results were observed on deltamethrin-exposed freshwater fish Aphanius dispar that showed the changes like vacuolization, lifting of the lamellar epithelium and fusion of secondary lamellae (Al-Ghanbousi et al. 2012). The histological responses in the gills of fish were mostly associated with circulatory disturbances and regressive and progressive changes (Van Dyk et al. 2009).

In the liver section, the control tissue showed normal hepatocytes. The AgNPs-treated fish had congestive enlargement of liposomes which lead to vacuolar degenerations in liver. The necrosis were seen at higher level in liver tissues of AgNPs-exposed fish. The section of the control muscle showed normal histological structures such as fiber bundles, connective tissue and arrangement of muscle bundles. The treated fish had an abnormal arrangement of muscle bundles, vacuolization in both liver and muscle. Muscle fibre inflammations were noticed in treated L. rohita. The earlier report of Capkin et al. (2010) concluded the similar toxic effect of pesticides on the vital organs of juvenile rainbow trout (Oncorhynchus mykiss).

\section{Conclusion}

This present study deals with the chemical synthesis of AgNPs and physically characterized by UV-Visible, FTIR, XRD, and HRTEM analysis. This investigation clearly demonstrated the impact of AgNPs on aquatic organisms. These AgNPs caused alterations in the haemotology, enzymes activities and histopathological parameters. From this experimental study, we suggest that before applications of AgNPs in various industrial sectors, the toxic potential must be carefully assessed and the effluents are also to be processed before it gets entered into the environment to protect the aquatic eco-systems as well as human lives.

Acknowledgments The authors are thankful to UGC-DAE CSR Indore for financial assistance through collaborative research project (Ref No: CSR-I/CRS-71/2012-2014/1016) and we are also grateful to DST-Fast Track (Ref. No: SR/FT/LS-21/2012) and UGC-SAPDRS-II for the Instrumentation facilities in the Department of Animal Science, Bharathidasan University, Tiruchirappalli. K. S. Rajkumar thank DST for the award of INSPIRE FELLOWSHIP (IF140546).

Open Access This article is distributed under the terms of the Creative Commons Attribution License which permits any use, distribution, and reproduction in any medium, provided the original author(s) and the source are credited.

\section{References}

Al-Ghanbousi R, Ba-Omar T, Victor R (2012) Effect of deltamethrin on the gills of Aphanius dispar : a microscopic study. Tissue Cell 44:7-14

Antony JJ, Sivalingam P, Siva D, Kamalakkannan S, Anbarasu K, Sukirtha R, Krishnan M, Achiraman S (2011) Comparative evaluation of antibacterial activity of silver nanoparticles synthesized using Rhizophora apiculata and glucose. Colloids Surf B 88:134-140

Banu A, Vandana R, Ranganath E (2011) Silver nanoparticle production by Rhizopus stolonifer and its antibacterial activity against extended spectrum $\beta$-lactamase producing (ESBL) strains of Enterobacteriaceae. Mater Res Bull 46:1417-1423

Battaglini P, Andreozzi G, Antonucci R, Arcamone N, De Girolamo P, Ferrara L, Gargiulo G (1993) The effects of cadmium on the gills of the goldfish Carassius auratus (L) metal uptake and histochemical changes. Comp Biochem Physiol C 104:239-247

Benn TM, Westerhoff P (2008) Nanoparticle silver released into water from commercially available sock fabrics. Environ Sci Technol 42(11):4133-4139

Blaxhall PC (1972) The haematological assessment of the health of fresh water fish. A review of selected literature. J Fish Biol 4:593-604

Calibrone AL (1985) Hand book of methods for oxygen radical research. CRC, Boca Raton, p 283

Capkin E, Terzi E, Boran H, Yandi I, Altinok I (2010) Effects of some pesticides on the vital organs of juvenile rainbow trout (Oncorhynchus mykiss). Tissue Cell 42:376-382

Diniz MS, de Matos APA, Lourenço J, Castro L, Peres I, Mendonça E, Picado A (2013) Liver alterations in two freshwater fish species (Carassius auratus and Danio rerio) following exposure to different $\mathrm{TiO}_{2}$ nanoparticle concentration. J Microsc Microanal 19:1131-1140

Estiarte M, Peuuelas J, Sardans BA, Emmett A, Soweby C, Beier IK, Schmidt A, Tietema MJM, Van Mectern E, Kvacs P, Mathe P, De Angelis G, De Dato G (2008) Root-surface phosphatase activity in shrublands across a European gradient: effects of warming. J Env Bio 29:25-29

Federici G, Shaw BJ, Handy RD (2007) Toxicity of titanium dioxide nanoparticles to rainbow trout, (Oncorhynchus mykiss): gill injury, oxidative stress, and other physiological effects. Aquat Toxicol 84:415-430

Griffitt RJ, Weil R, Hyndman KA, Denslow ND, Powers K, Taylor D (2007) Exposure to copper nanoparticles causes gill injury and acute lethality in zebra fish (Danio rerio). Environ Sci Technol 41:8178-8186

Habig WH, Pabst MJ, Jakoby WB (1974) Glutathione S transferases. The first enzymatic step in mercapturic acid formation. J Bio Chem 251:7130-7139

Hussain S, Boland S, Baeza-Squiban A (2009) Oxidative stress and proinflammatory effects of carbon black and titanium dioxide nanoparticles: role of particle surface area and internalized amount. J Toxicol 260:142-149

Jia HY, Liu Y, Zhang XJ, Han L, Du B, Tian Q (2009) Potential oxidative stress of gold nanoparticles by induced-NO releasing in serum. J Am Chem Soc 131(1):40-41

Kaewamatawong T, Shimada A, Okajima M, Inoue H, Morita T, Inoue K (2006) Acute and subacute pulmonary toxicity of low 
dose of ultrafine colloidal silica particles in mice after intratracheal instillation. Toxicol Pathol 34:958-965

Kanipandian N, Kannan S, Ramesh R, Subramanian P, Thirumurugan R (2014) Characterization, antioxidant and cytotoxicity evaluation of green synthesized silver nanoparticles using Cleistanthus collinus extract as surface modifier. Mater Res Bull 49:494-502

Kanipandian N, Thirumurugan R (2014) A feasible approach to phyto-mediated synthesis of silver nanoparticles using industrial crop Gossypium hirsutum (cotton) extract as stabilizing agent and assessment of its in vitro biomedical potential. Ind Crop Prod 55:1-10

King-Heiden TC, Wiecinski PN, Mangham AN, Metz KM, Nesbit D, Pedersen JA (2009) Quantum dot nanotoxicity assessment using the zebra fish embryo. Environ Sci Technol 43:1605-1611

Lemaire-Gony S, Lemaire P (1992) Interactive effects of cadmium and benzo (a) pyrene on cellular structure and biotransformation enzymes of the liver of the European eel Anguilla anguilla. Aquat Toxicol 22:145-160

Mac Nee W, Donaldson K (2003) Mechanism of lung injury caused by PM10 and ultrafine particles with special reference to COPD. Eur Respir J 21(40):47-51

Marklund S, Marklund G (1974) Involvement of superoxide anion radical in the autooxidation of pyrogallol and a convenient assay for superoxide dismutase. Eur J Biochem 47:469-474

Masciangioli T, Zhang WX (2003) Environmental technologies at the nanoscale. Environ Sci Technol 37(5):102-108

Michell RH, Karnovsky MJ, Karnovsky ML (1970) The distributions of some granule-associated enzymes in guineapig polymorph nuclear leucocytes. Biochem J 116:207-216

Nohynek GJ, Lademann J, Ribaud C, Roberts MS (2007) Grey Goo on the skin? Nanotechnology, cosmetic and sunscreen safety. Crit Rev Toxicol 37(3):251-277

Paulraj P, Janaki N, Sandhya S, Pandian K (2011) Single pot synthesis of polyaniline protected silver nanoparticles by interfacial polymerization and study its application on electrochemical oxidation of hydrazine. Colloids Surf A 377:28-34

Ramesh R, Kavitha P, Kanipandian N, Arun S, Thirumurugan R, Subramanian P (2013) Alteration of antioxidant enzymes and impairment of DNA in the $\mathrm{SiO}_{2}$ nanoparticles exposed zebra fish (Danio rerio). Environ Monit Assess 185:5873-5881

Rashid MU, Bhuiyan MKH, Quayum ME (2013) Synthesis of silver nano particles (Ag-NPs) and their uses for quantitative analysis of vitamin C tablets. J Pharm Sci 12(1):29-33

Singh N, Manshian B, Jenkins GJS (2009) Nano genotoxicology: the DNA damaging potential of engineered nanomaterials. Biomaterials 30(23):3891-3914

Smith CJ, Shaw BJ, Handy RD (2007) Toxicity of single walled carbon nanotubes to rainbow trout, (Oncorhynchus mykiss): respiratory toxicity, organ pathologies, and other physiological effects. Aquat Toxicol 82:94-109

Takashima F, Hibiya T (1995) An Atlas of Fish Histology. Normal and Pathological Features, 2nd edn. Kodansha Ltd., Tokyo

Van Dyk JC, Marchand MJ, Pieterse GM, Barnhoorn IEJ, Bornman MS (2009) Histological changes in the gills of Clarias gariepinus (Teleostei: Clariidae) from a polluted South African urban aquatic system. Afr J Aqua Sci 34(3):283-291

Vignesh V, Anbarasi KF, Karthikeyeni S, Sathiyanarayanan G, Subramanian P, Thirumurugan R (2013) A superficial phytoassisted synthesis of silver nanoparticles and their assessment on hematological and biochemical parameters in Labeo rohita (Hamilton, 1822). Colloids Surf A 439:184-192

Vivek R, Thangam R, Muthuchelian K, Gunasekaran P, Kaveri K, Kannan S (2012) Green biosynthesis of silver nanoparticles from Annona squamosa leaf extract and its in vitro cytotoxicity effect on MCF-7 cells. Process Biochem 47(12):2405-2410

Xiong D, Fang T, Yu L, Sima X, Zhu W (2011) Effects of nano-scale $\mathrm{TiO}_{2}, \mathrm{ZnO}$ and their bulk counterparts on zebra fish: acute toxicity oxidative stress and oxidative damage. Sci Total Env 409:1444-1452

Young IS, Woodside JV (2001) Antioxidants in health and disease. J Clin Pathol 54:176-186

Zhu S, Oberdörster E, Haasch ML (2006) Toxicity of an engineered nanoparticle (fullerene, C60) in two aquatic species, Daphnia and fathead minnow. J Mar Env Res 62:5-9 